Georgia State University

ScholarWorks @ Georgia State University

Computer Information Systems Faculty

Publications

Department of Computer Information Systems

2006

\title{
Firm Performance Impacts of Digitally Enabled Supply Chain Integration Capabilities
}

\author{
Arun Rai \\ Georgia State University, arunrai@gsu.edu \\ Ravi Patnayakuni \\ University of Alabama, Huntsville, r.patnayakuni@uah.edu \\ Nainika Seth \\ University of Alabama, Huntsville, patnayn@email.uah.edu
}

Follow this and additional works at: https://scholarworks.gsu.edu/cis_facpub

Part of the Management Information Systems Commons

\section{Recommended Citation}

Rai, A., Patnayakuni, R., Patnayakuni, N., Firm Performance Impacts of Digitally-enabled Supply Chain Integration Capabilities, MIS Quarterly, 30 (2), June 2006, 225-246. http://misq.org/firm-performanceimpacts-of-digitally-enabled-supply-chain-integration-capabilities.html.

This Article is brought to you for free and open access by the Department of Computer Information Systems at ScholarWorks @ Georgia State University. It has been accepted for inclusion in Computer Information Systems Faculty Publications by an authorized administrator of ScholarWorks @ Georgia State University. For more information, please contact scholarworks@gsu.edu. 


\section{FiRm PeRformance IMPACtS OF Digitally ENABLEd SUPPLY CHAIN INTEGRATION CAPABILITIES ${ }^{1}$}

By:

\author{
Arun Rai \\ Center for Process Innovation and \\ Department of Computer Information \\ Systems \\ J. Mack Robinson College of Business \\ Georgia State University \\ Atlanta, GA 30303 \\ U.S.A. \\ arunrai@gsu.edu \\ Ravi Patnayakuni \\ Department of Accounting and \\ Information Systems \\ University of Alabama in Huntsville \\ Huntsville, AL 35899 \\ U.S.A. \\ r.patnayakuni@uah.edu \\ Nainika Seth \\ Department of Accounting and \\ Information Systems \\ University of Alabama in Huntsville \\ Huntsville, AL 35899 \\ U.S.A. \\ patnayn@email.uah.edu
}

${ }^{1} \mathrm{~V}$. Sambamurthy was the accepting senior editor for this paper. Rob Fichman was the associate editor. Ted H. Clark and Prabhudev Konana served as reviewers. The third reviewer chose to remain anonymous.

\begin{abstract}
Best practice exemplars suggest that digital platforms play a critical role in managing supply chain activities and partnerships that generate performance gains for firms. However, there is limited academic investigation on how and why information technology can create performance gains for firms in a supply chain management (SCM) context. Grant's (1996) theoretical notion of higher-order capabilities and a hierarchy of capabilities has been used in recent information systems research by Barua et al. (2004), Sambamurthy et al. (2003), and Mithas et al. (2004) to reframe the conversation from the direct performance impacts of IT resources and investments to how and why IT shapes higher-order process capabilities that create performance gains for firms. We draw on the emerging IT-enabled organizational capabilities perspective to suggest that firms that develop IT infrastructure integration for SCM and leverage it to create a higher-order supply chain integration capability generate significant and sustainable performance gains. A research model is developed to investigate the hierarchy of IT-related capabilities and their impact on firm performance. Data were collected from 110 supply chain and logistics managers in manufacturing and retail organizations. Our results suggest that integrated IT infrastructures enable firms to develop the higher-order capability of supply chain process integration. This capability enables firms to unbundle information flows from physical flows, and to share information with their supply chain partners to create information-based approaches for superior demand planning, for the staging and movement of physical products, and for streamlining voluminous and complex financial work processes. Furthermore, IT-enabled supply chain integration capability results in significant and sustained firm performance gains, especially in operational excellence and revenue growth. Managerial
\end{abstract}


initiatives should be directed at developing an integrated IT infrastructure and leveraging it to create process capabilities for the integration of resource flows between a firm and its supply chain partners.

Keywords: Supply chain integration, IT infrastructure, supply chain management, operational excellence, revenue growth, customer relationships

\section{Introduction}

Capabilities of core interorganizational processes, such as customer relationship management, supply chain management, and contract manufacturing, are suggested as critical to firm performance (Hagel and Singer 1999; Rayport and Sviokla 1995; Sambamurthy et al. 2003). Their digitization across the extended enterprise is being enabled by Web technologies, workflow tools, portals for customers, suppliers, and employees, and information technology innovations targeted at supply chains and customer relationships. Firms are investing in these technologies and related partnerships to develop their extended enterprise capabilities.

Supply chain management (SCM) is a digitally enabled interfirm process capability that has been receiving significant attention. Practitioner forums such as the Supply Chain Management Council have been established and special issues of Decision Sciences and Journal of Operations Management have been recently published on the topic. However, in spite of the key role of IT in the SCM phenomenon, thus far limited scholarly investigation has been undertaken by the Information Systems community. Our objective is to present a theoretical viewpoint, supported by empirical evidence, on how IT enables supply chain integration capability to yield performance gains for firms.

Supply chain strategies focus on improvement and innovation of end-to-end processes between firms and their customers and suppliers (Lee 2000; Tyndall et al. 1998). Case studies document problems caused by supply chain fragmentation across different industries and best practice reports profile the potential of IT to address them (Enslow 2000; Rai and Sambamurthy 2002; Simchi-Levi et al. 2000). These descriptions suggest that supply chain integration (1) requires partners to share information and develop globally optimal plans (Ho et al. 2002; Simchi-Levi et al. 2000), (2) optimizes the staging and flow of materials by leveraging the visibility of resources (Lee 2000), and (3) streamlines financial operations such as billing and payments that are interdependent on other activities such as ordering and delivery
(Mabert and Venkatraman 1998). In summary, supply chain integration encompasses the integration of information flows, physical flows, and financial flows between a firm and its supply chain partners.

Supply chain integration can be hampered by fragmented IT infrastructures that constrain information flows and activity coordination (Barua et al. 2004; Sambamurthy et al. 2003). In contrast, integrated IT infrastructures that are characterized by common data standards and integrated applications enable flows of information and coordination of activities across functional units, geographic regions, and value network partners (Broadbent et al. 1999). As illustrated below, such integrated IT infrastructures for SCM are being exploited by best-practice firms for superior performance.

1. United Parcel Service, one of the world's largest logistics service providers, has redefined its services from physical movement of packages to solutions for "synchronized commerce." Their IT architectures enable data integrity and connectivity with customers' applications, providing real-time visibility of inventory that is stored or in-transit. This visibility can be leveraged by customers to improve inventory management, asset efficiencies, and market responsiveness. ${ }^{2}$

2. Cisco Systems has created a digital platform for the near real-time transmission of information between customers, contract manufacturers, and logistics providers. This enables responsive collaborative planning and efficient coordination of resources across its global supply chain (Enslow 2000; Sabath and Frentzel 1997).

3. By leveraging IT to manage its supply chain, Dell Computers has achieved dramatic results in performance (Magretta 1998). Dell's Web-enabled supply chain enables it to maintain only four days of inventory and to achieve negative cash conversion cycles with respect to its financial flows (Fields 2003). ${ }^{3}$

Despite the critical role of IT in SCM, theoretical and empirical research pertaining to digitally enabled supply chain integration phenomenon has been limited and piecemeal (Sahin and Powell 2002). We draw on concepts from the interrelated literature streams of organizational and IT-

\footnotetext{
${ }^{2}$ Personal conversation with Laurie Johnson, Chief Information Officer, UPS Supply Chain Solutions, Atlanta, Georgia.

${ }^{3}$ It is important to recognize that Dell has undertaken several non-IT related initiatives, such as colocation of supplier warehouses, pricing, and incentive schemes, to shape its supply chain integration capabilities.
} 
enabled capabilities, IT infrastructure, and supply chain operations to develop key constructs and relationships associated with IT-enabled supply chain integration. Specifically, we focus on the constructs of IT infrastructure integration for SCM, supply chain integration capability, sustained firm performance, and the relationships among them. We test our model by developing and validating measures for the constructs and examine the empirical validity of posited relationships. Specifically, we address the following questions:

1. What key properties define supply chain process integration capability between a focal firm and its supply chain partners?

2. How does IT infrastructure integration for SCM impact supply chain process integration capability?

3. What are the performance consequences of IT-enabled supply chain integration capability for a focal firm?

In the next section, we present the research framework used for the study. We then specify constructs and relationships associated with our research model. Subsequently, we describe the empirical study, including instrument development, data collection, measurement validation, and results. We then interpret our findings and offer some concluding comments in the final section.

\section{The Research Framework}

Traditionally, SCM issues have been investigated by operations management researchers with a focus on functional problems, such as facilities location and transportation (Geoffrion and Powers 1995), inventory management (Cohen and Lee 1998; Mabert and Venkatraman 1998), materials management, purchasing, and distribution (Scott and Westbrook 1991; Turner 1993). Similarly, IT impacts in the context of SCM have been mostly investigated with a focus on specific technologies and innovations, such as EDI (Srinivasan and Kekre 1994), cellular manufacturing (Black 1991), and vendor-managed inventory (Ellinger et al. 1999). Recent recommendations encourage researchers to focus investigations on the interorganizational capabilities that integrate a firm with its network of suppliers and customers to create value for firms (Ho et al. 2002; Narsimhan and Jayram 1998).

Extending on the resource-based view of the firm (Barney 1991), higher-order organizational capabilities are suggested as a source of firm performance in the strategic management literature (Grant 1996; Teece et al. 1997) and, more recently, in the IS literature (Barua et al. 2004; Mithas et al. 2004; Sambamurthy et al. 2003). According to this perspective, a firm must develop capabilities to acquire, integrate, reconfigure, and release resources that are embedded in their social, structural, and cultural context. Developing these capabilities is a long-term process that requires firms to make a series of linked strategic decisions and moves related to IT resources so as to blend them with organizational processes and knowledge resources (Barua et al. 2004).

Viewed from the perspective of organizational capabilities and resource-based theory, commonly available IT resources cannot by themselves create sustained performance gains for a firm (Floyd and Wooldridge 1990; Powell and DentMicallef 1997; Zahra and Covin 1993). Accordingly, conceptual distinctions have been made between IT components broadly available in the marketplace, integrated IT platforms that require significant time and expertise for development (Weill and Broadbent 1998), and IT-enabled processes that deeply embed capabilities of IT platforms into organizational processes (Bharadwaj 2000).

A well-integrated IT platform is much more than individual physical components. It requires standards for the integration of data, applications, and processes to be negotiated and implemented in order for real-time connectivity between distributed applications to be achieved (Ross 2003; Weill and Broadbent 1998). From our perspective, an integrated IT infrastructure enables consistent and real-time transfer of information between SCM-related applications and functions that are distributed across partners.

Such integrated IT infrastructures for SCM can be blended with interorganizational processes to develop higher-order capabilities for demand sensing, operations and workflow coordination, and global optimization of resources. These capabilities require firms to unbundle the three complementary flows of materials (Stevens 1990), information (Lee et al. 1997), and finances (Mabert and Venkatraman 1998), and integrate each of them with supply chain partners. Accordingly, we consider information, physical, and financial flows in our framing of a focal firm's supply chain integration capability.

Based on our discussion, we present the framework for our study in Figure 1. IT infrastructure integration for SCM represents a lower-order capability that can be leveraged to develop a higher-order process capability (i.e., supply chain process integration), which is a source of significant and sustained performance gains for a firm. Given that we are sug- 


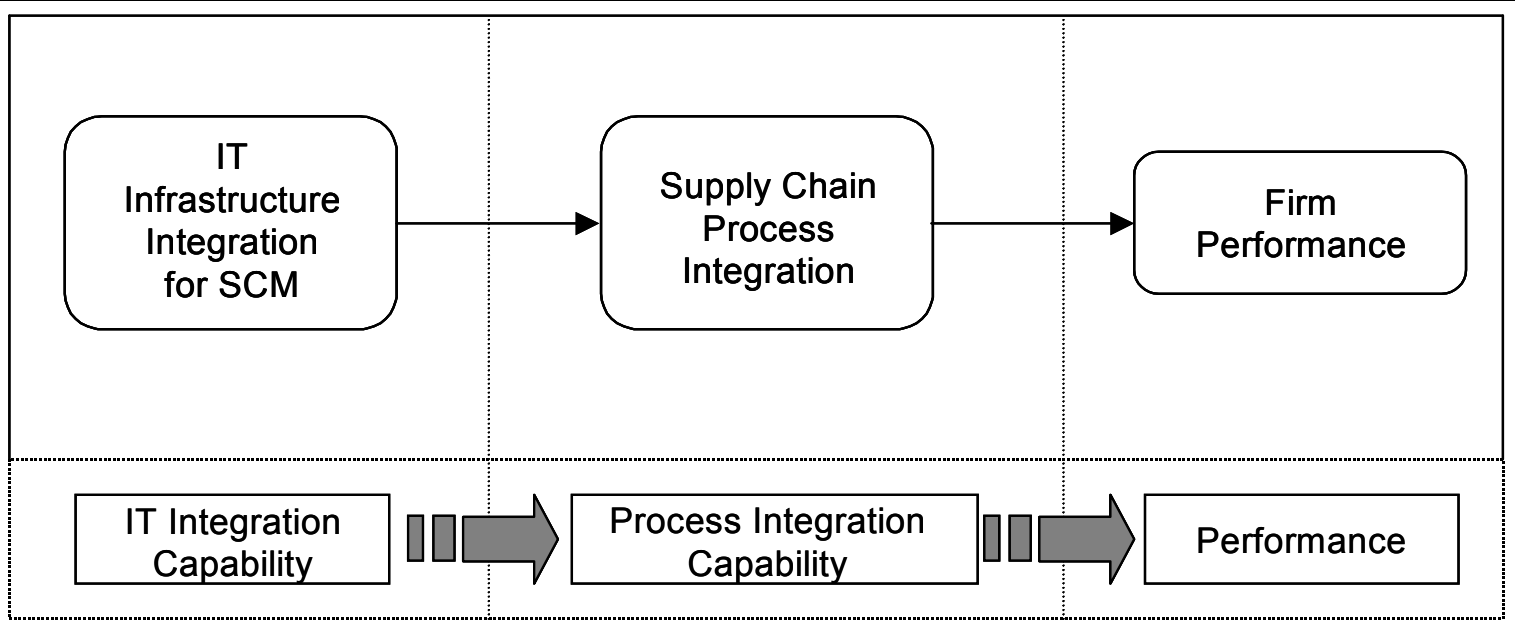

Figure 1. Research Framework

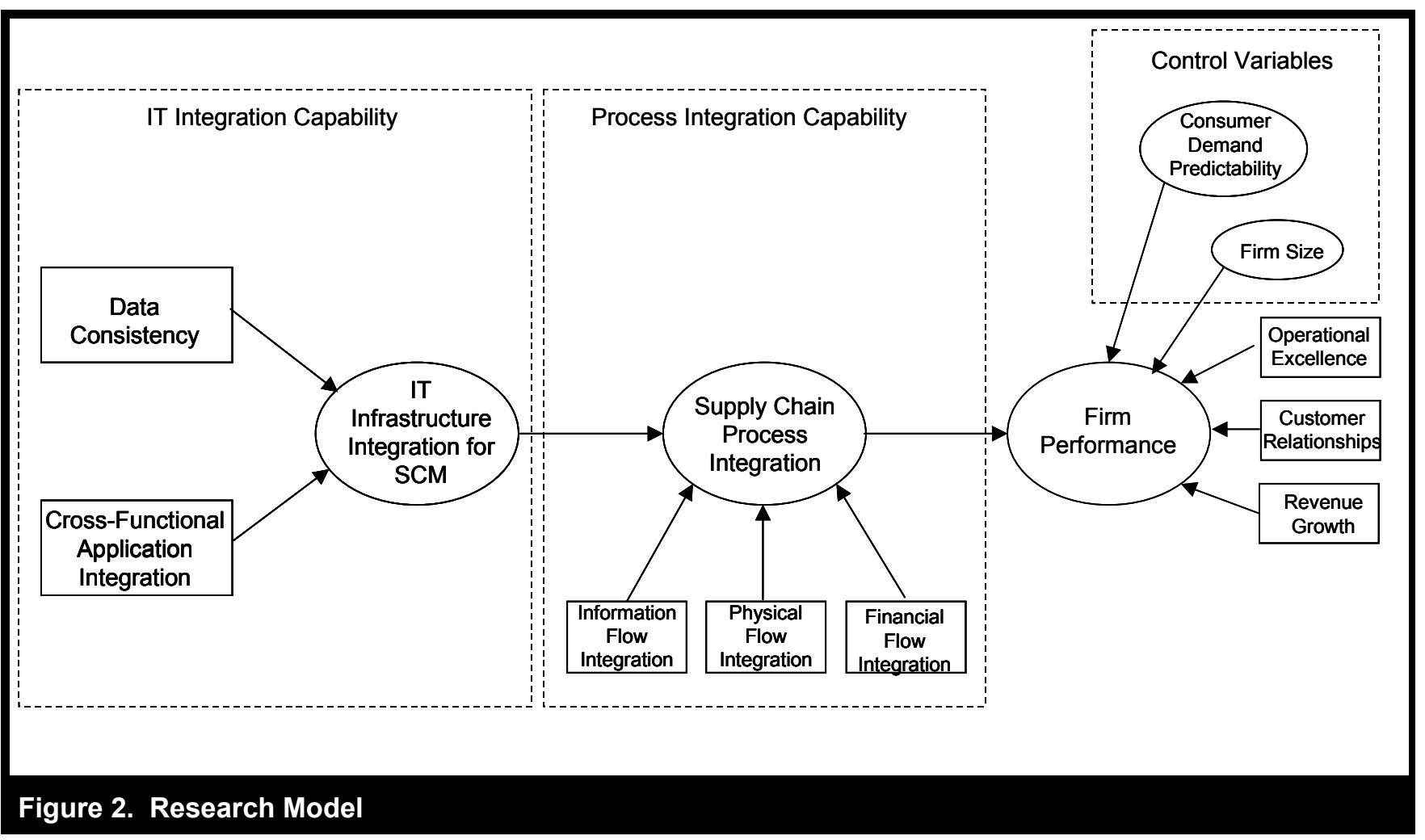


Table 1. Construct Definitions

Construct*

Definition

IT Infrastructure Integration for SCM:

The degree to which a focal firm has established information systems for the consistent and high-velocity transfer of supply chain-related information within and across its boundaries.

\begin{tabular}{|c|c|}
\hline Data Consistency & $\begin{array}{l}\text { The degree to which common data definitions and consistency in stored data have been } \\
\text { established across a focal firm's supply chain. }\end{array}$ \\
\hline $\begin{array}{l}\text { Cross-Functional SCM } \\
\text { Application Systems Integration }\end{array}$ & $\begin{array}{l}\text { The degree of real-time communication of a focal firm's function-specific supply chain } \\
\text { management applications with each other and related ERP and CRM applications. }\end{array}$ \\
\hline \multicolumn{2}{|c|}{$\begin{array}{l}\text { Supply Chain Process Integration Capability: } \\
\text { The degree to which a focal firm has integrated its physical, financial, and information flows with its supply chain } \\
\text { partners. }\end{array}$} \\
\hline Physical Flow Integration & $\begin{array}{l}\text { The degree to which a focal firm uses global optimization with its supply chain partners to } \\
\text { manage the stocking and flow of materials and finished goods. }\end{array}$ \\
\hline Information Flow Integration & $\begin{array}{l}\text { The extent of operational, tactical,and strategic information sharing that occurs between } \\
\text { a focal firm and its supply chain partners. }\end{array}$ \\
\hline Financial Flow Integration & $\begin{array}{l}\text { The degree to which financial flows between a focal firm and its supply chain partners is } \\
\text { driven by workflow events. }\end{array}$ \\
\hline \multicolumn{2}{|c|}{$\begin{array}{l}\text { Firm Performance: } \\
\quad \text { The degree to which a focal firm has superior performance relative to its competition. }\end{array}$} \\
\hline Operations Excellence & $\begin{array}{l}\text { The degree to which a focal firm is better than its competitors in its responsiveness and } \\
\text { generation of productivity improvements. }\end{array}$ \\
\hline Customer Relationship & $\begin{array}{l}\text { The degree to which the focal firm's relationship with customers and information about } \\
\text { their preferences is better than its competitors. }\end{array}$ \\
\hline Revenue Growth & $\begin{array}{l}\text { The degree to which the focal firm's increase in revenue from current and new products } \\
\text { and markets is more than its competitors. }\end{array}$ \\
\hline
\end{tabular}

*Both second-order constructs and their sub-constructs are defined in this table. The italicized definitions are associated with second-order constructs.

gesting a hierarchy of capabilities for firm performance, a direct effect between IT infrastructure integration for SCM and firm performance is not specified.

\section{The Research Model}

Figure 2 schematically represents the research model and Table 1 summarizes the definitions of latent constructs and sub-constructs. The measurement items used for each construct are included in Appendix A.

\section{Firm Performance}

We are concerned with a firm's aggregate performance relative to its competition. Operations excellence, revenue growth, and customer relationships, recognized as important dimensions of firm performance (Slywotzky et al. 2000), are three aspects of performance that we consider. Operations excellence is defined as a focal firm's responsiveness to customers and improvements in productivity relative to its competition. It has been noted that firms must balance operations costs and service level performance in terms of lead times to meet customer needs (Fisher 1997; Simchi-Levi et al. 2000). In addition, firms need to achieve marketfocused performance (Malhotra et al. 2005) that encompasses customer relationships (Groves and Valsamakis 1998) and revenue growth (Kalwani and Naravandas 1995; Moorman 1995). Customer relationships focus on the bond and loyalty between a focal firm and its customers, and the focal firm's intimate knowledge about customer-related preferences. Growth in revenues includes sales from existing products and from new products and markets (Zahra and George 2002). 
There is some evidence that supply chain integration impacts the three dimensions of performance considered here. For instance, it has been suggested that integration of supply chains can enhance a firm's time-based competitiveness by compressing cycle times (Hult et al. 2004). Integrated supply chains provide operational visibility, coordination of plans, and streamlined flow of goods that compress the time interval between a customer's request for a product or service and its delivery (Hult et al. 2004; Tyndall et al. 1998). This capability is also suggested to positively impact top- and bottomline financial performance (Lee et al. 1997; Simchi-Levi et al. 2000), improve customer relationships, and promote market growth (Goldhar and Lei 1991; Tyndall et al. 1998). We examine whether aggregate performance of a firm, as assessed by operations excellence, revenue growth, and customer relationships, is influenced by supply chain process integration.

\section{Supply Chain Process Integration Capability and its Impacts on Firm Performance}

The literature identifies important flows across the supply chain to include materials (Stevens 1990), information (Lee et al. 1997), and finances (Mabert and Venkatraman 1998). Accordingly, supply chain process integration is defined as the degree to which a focal firm has integrated the flow of information, materials, and finances with its supply chain partners. Although knowledge flows are discussed in the literature (Carlile 2002), they are sometimes overlapped in their definition to include information flows, and we do not consider them as a distinct flow in our investigation. Accordingly, supply chain process integration is conceptualized as a formative construct with three sub-constructs: information flow integration, physical flow integration, and financial flow integration.

\section{Information Flow Integration}

Information flow integration is defined as the extent to which operational, tactical, and strategic information are shared between a focal firm and its supply chain partners. Specifically, we consider the sharing of demand-related information, inventory and sales positions, production and delivery schedules, and performance metrics as indicators of information flow integration.

Seidmann and Sundarajan (1997) note that operational information sharing can leverage the economies of scale and expertise across organizations. Inventory holding information, when shared, can reduce total inventory in the supply chain (Lee et al. 1997). Similarly, production and delivery schedules can be shared to enhance operational efficiencies through improved coordination of allocated resources, activities, and roles across the supply chain (Lee et al. 2000). Tactical information sharing can encompass performance metrics associated with execution of tasks and their outcomes. Finally, strategic information sharing occurs when the information possessed by a firm generates little value by itself, but creates strategic value when shared (Seidmann and Sundarajan 1997). For instance, sharing of sales information by buyers with sellers creates value through improved demand planning, forecasting, and replenishment. It has been shown that lack of sharing of actual sales information substantially distorts the demand signal as it travels upstream across the supply chain. The phenomenon of upstream amplification of error in the demand signal is called the bullwhip effect ${ }^{4}$ (Lee et al. 1997) and causes problems such as excessive or inadequate inventory, poor production and capacity planning, cash flow utilization, and customer service.

Information sharing allows retailers, manufacturers, and suppliers to improve forecasts, synchronize production and delivery, coordinate inventory-related decisions, and develop a shared understanding of performance bottlenecks (Lee and Whang 1998; Simchi-Levi et al. 2000). By substituting information for inventory holdings (Milgrom and Roberts 1988), information flow integration can improve operational performance by reducing inventory costs, enhancing capital and cash flow utilization, and improving cycle times. By improving the precision of demand estimation through collaborative forecasting, and facilitating supply and demand alignment, information sharing can strengthen bonds with customers and generate increased revenues from existing products and new products and markets (Anderson et al. 1994; Mohr and Nevin 1990).

\section{Physical Flow Integration}

Physical flow integration is defined as the degree to which a focal firm uses global optimization with its supply chain partners to manage the stocking and flow of materials and finished goods. Downstream flows consist of raw materials, subassemblies, and finished goods, while upstream flows consist of products that are returned or need to be repaired. Specific initiatives that have been suggested to improve global optimization of physical flows include just-in-time delivery (Lowson et al. 1999), automatic replenishment,

\footnotetext{
${ }^{4}$ Managerial practices, such as price fluctuations and forward buying, that promote the bullwhip effect are discussed in Lee and Whang (1998). We focus our attention here on information flow integration and its ability to counter the bullwhip effect.
} 
vendor managed inventory programs (Daugherty et al. 1999; Ellinger et al. 1999), and contracting with logistics providers for inventory management services (Richardson 1999; Van Hoek 2000). In addition, distribution networks can be reconfigured to optimally stage inventory across the supply chain (Arntzen et al. 1995; Vidal and Goetschalckx 2000). We identify multi-echelon optimization of costs, just-in-time deliveries, joint management of inventory with suppliers and logistics partners, and distribution network configuration for optimal staging of inventory as indicators of physical flow integration.

Physical flow integration can improve productivity by reducing costs of production, transportation, warehousing, and logistics (Goldhar and Lei 1991). It can enable firms to cut lot sizes, increase order frequency, cut buffer inventory (Kaeli 1990; Lee and Billington 1992), reduce purchasing costs, improve material handling, and invest in reliable suppliers (Schneidrjans 1993). Other operational performance benefits include fewer stock outs, more efficient stocking, less need for safety stock, and improved selling space productivity (Ellinger et al. 1999). By increasing responsiveness to customer demand through strategies such as postponement of differentiation (Feitzinger and Lee 1997), physical flow integration can improve customer relationships and customer service (Ellinger et al. 1999; Gustin et al. 1995). Finally, such integration is expected to improve long-term competitiveness and growth (Goldhar and Lei 1991).

\section{Financial Flow Integration}

Financial flow integration is defined as the degree to which exchange of financial resources between a focal firm and its supply chain partners is driven by workflow events. Financial processes were among the earliest business processes that were reengineered to reduce delays, improve productivity, and eliminate redundant tasks (Hammer 1990). Yet, organizations often do not have a consistent view of their financial flows with their upstream and downstream partners (McCormack and Johnson 2003). Important downstream flows to be managed include prices, invoices, and credit terms, and essential upstream flows to be coordinated include payments and account payables.

Financial flow integration can enable better working capital and cash flow management through event-based triggering of payables and receivables; for instance, electronic payment can be triggered upon delivery of goods. Event-based financial workflows can reduce costs associated with billing, payment processing, and dispute handling, and can shorten the invoicing and receivables cycle time, accelerate payments, and improve the availability of financial information for decision-making (Greenfield et al. 2001). Reduced delays, accelerated payments, and collection of customer preferences with billing and invoicing transactions can result in improved customer relationships. Finally, financial flow integration can impact revenue growth by improving cash flow availability for production ramp-up when demand swings upward, or for exploration of new product lines.

\section{IT Infrastructure Integration for SCM}

We define IT infrastructure integration as the degree to which a focal firm has established IT capabilities for the consistent and high-velocity transfer of supply chain-related information within and across its boundaries. IT infrastructure integration is conceptualized as a formative construct with two subconstructs: data consistency and cross-functional SCM application systems integration.

\section{Data Consistency}

Data consistency is defined as the degree to which common data definitions and consistency in stored data have been established across a focal firm's supply chain. There are significant data consistency problems in large distributed database or intermittently connected distributed systems, such as mobile computing environments (Pitoura and Bhargava 1999). Even greater problems occur in disparate and fragmented systems spread across organizational boundaries, such as supply chains. Data consistency in supply chains will be enabled by common data definitions for key entities, such as customer and product, as well as automated systems for accurate data capture. This consistency should enable process integration (Huber 1990; Malone et al. 1987), including the integration of information, financial, and physical flows.

\section{Cross-Functional SCM Application Systems Integration}

Cross-functional SCM application systems integration is defined as the degree of real-time communication of a focal firm's function-specific SCM applications with each other and related ERP and CRM applications. Such connectivity enables the management of cross-functional process dependencies in a supply chain (Rai, Bush, and Tiwana 2002; Rai, Ruppel, and Lewis 2002). Note that application integration is concerned with a firm's ability to interface functionspecific supply chain applications with each other in realtime, while the information flow integration construct 
described earlier is concerned with the content of operational, tactical, and strategic information actually shared among partners.

We consider integration of applications for supply chain planning and execution, and their integration with ERP and CRM systems; together they characterize the applications infrastructure for end-to-end management of supply chains (Kalakota and Robinson 1999). Planning applications are designed to support planning for critical functions such as procurement, production, transportation, and warehousing. Execution applications are designed to support execution of order management, replenishment, production, and distribution. Integrated planning applications provide a capability to generate cross-functional information about the supply chain and develop globally optimal plans (Kalakota and Robinson 1999). Similarly, integrated execution applications provide the capability to generate supply chain-wide visibility of processes and coordinate global execution. Finally, integrated supply chain, ERP, and CRM applications should facilitate the coordination of supplier- and customer-facing processes with internal firm processes.

\section{Control Variables}

Fisher (1997) makes a distinction between functional and innovative products. While functional products have long product lifecycles and low forecasting errors, innovative products have short product lifecycles and high forecasting errors. In addition, profit margins for innovative products are significantly higher than those for functional products. Since firm performance can be influenced by demand predictability at the end-consumer level based on the type of products in question, we specify consumer demand predictability as a control variable. In addition, since larger firms may be in a better position to achieve performance gains due to their ability to garner scale efficiencies (Hitt et al. 2002), we specify firm size as a control variable.

\section{The Empirical Study}

\section{Instrument Development}

Data were collected using a carefully developed self-report survey instrument based on guidelines and exemplars in the literature, for example, Straub (1989) and Sethi and King (1991). We systematically developed and validated measures for the supply chain process integration and IT infrastructure integration constructs that are being introduced in this study.
Past literature was reviewed to specify a set of items that ensured content and face validity and to achieve minimal overlap between constructs (Cronbach 1971; Kerlinger 1986). Items associated with these constructs used a seven-item Likert type scale where respondents were asked to state their agreement with a given statement on a scale that ranged from "strongly agree" to "strongly disagree" with its midpoint anchored as "neither agree nor disagree." Respondents were asked to select the organization's primary product(s) or product line(s) while responding to the questions on these constructs. Primary product(s) or product line(s) were defined as those that command a significant proportion of company revenues, usually 15 to 20 percent, or greater.

Subjective measures were used for operational excellence, revenue growth, and customer relationships. The approach has been widely used in organizational research, as senior managers have reasonable information and perspective about organizational performance (Dess 1987; Lawrence and Lorsch 1967; Powell 1992). Subjective measures are also often preferred as differences in accounting conventions and practices can confound the comparison of financial measures (Powell and Dent-Micallef 1997). Further, some performance measures, such as timeliness and customer relationships, do not have equivalent accounting-based performance measures. A semantic comparison scale was used for subjective organizational performance where respondents were asked to rate the performance of their organization in comparison to their competitors as "much better than average," "better than average," "same as competitors-average," "slightly less than average" or "much less than average." However, in order to examine the validity of the subjective measures of performance and guard against the risk of common-method bias, objective accounting-based measures of performance were collected from public sources for a subset of firms in our sample. ${ }^{5}$

Firm size and consumer demand predictability were specified as control variables. Total number of full-time equivalent employees was used as a measure of firm size and consumer demand predictability was measured using a two-item scale that assessed length of product lifecycle and forecast error for products (Fisher 1997).

Given that several measures are being developed for the first time, great care was taken to assess content validity. The items were first independently evaluated by each researcher and then in their joint meetings until there was unanimous

\footnotetext{
${ }^{5}$ Our sample included private organizations and subsidiaries of public organizations for which accounting-based measures of performance were unavailable from public sources.
} 
agreement on content validity. Two well-established IS scholars with experience in survey research and expertise in the subject domain subsequently evaluated the instrument. After incorporating suggested changes, the first phase of the pilot test was conducted with nine faculty members who are actively researching the strategic use of IT with a focus on interorganizational capabilities. In addition to requesting comments on items and instructions, they were asked to respond to semi-structured questions on each measure's content validity. Based on their feedback, the instrument was modified and then tested using a similar approach with 10 supply chain and logistics managers in the greater Philadelphia region. Telephone and e-mail discussions were conducted with these managers to obtain clarifications and ensure that adjustments made addressed their expressed concerns.

\section{Data Collection}

A mailing list of supply chain and logistics managers was compiled from the list of attendees of the annual conference of the Council of Logistics Management (CLM). Target respondents for the survey were considered to be senior or middle managers with direct responsibility for SCM or logistics function in the organization. Published attendee information included name, title, affiliation, and contact information; most attendees included an e-mail address in the contact information. Approximately 1,800 names were randomly selected from the list. All organizations that did not belong to manufacturing or retail industries (the first two digits of SIC codes 20 to 39 and 52 to 59) were removed from our sample. Since some of the conference participants were from the same organization, we examined listed professional titles to determine the most suitable target respondent. The final list consisted of 432 manufacturing and retail organizations.

The survey was first mailed out and then subsequently made available on a website; the address of the website was made available only to people on the mailing list. After the first conventional mailing, we sent e-mail reminders, providing respondents the option of receiving another copy of the survey by regular mail or completing the survey online. Our e-mail reminder provided an incentive of a $\$ 10.00$ Amazon.com gift certificate for each completed survey. After accounting for returned and undelivered mail and incorrect email addresses, 360 surveys were effectively mailed out. We received a total of 110 combined responses via return mail, Web, and e-mail. The effective response rate was 30.55 percent, which is considered acceptable for survey research.
We tested for nonresponse bias using analysis of variance techniques. Considering the last group of respondents as most likely to be similar to nonrespondents, a comparison of the first and last quartile of respondents provides a test of response bias in the sample (Armstrong and Overton 1977). The first and last 25 percent of respondents were compared on key study variables and firm revenue, which was used as a second proxy for firm size in addition to number of full-time employees. The tests did not indicate any response bias across these variables. Similar comparisons were made across participants who responded by regular mail and those who completed the survey online. The analysis indicated that the two groups were statistically similar on all demographic and study variables.

The median firm size was 4,000 employees and the median firm revenue was $\$ 1.5$ billion. The median firm realized less than 20 percent of its total revenue from online sales of products. Of the respondents, 45 percent were from the logistics function, 17 percent each were from the supply chain and distribution functions, 12 percent had responsibility for IT pertaining to the supply chain, 6 percent specified that their direct responsibility focused on e-commerce and digitization to support the supply chain, and 3 percent belonged to the purchasing function. Thus, our respondents hold positions that are well aligned with the subject matter of this investigation and are likely to be well informed of related initiatives within their firms.

\section{Measurement Validation}

Partial least squares (PLS) ${ }^{6}$ was used for the data analysis. This analytical approach is generally recommended for predictive research models where the emphasis is on theory development, whereas LISREL is recommended for confirmatory analysis and requires a more stringent adherence to distributional assumptions (Jöreskog and Wold 1982). Given that there have been very few empirical studies in this research context and little prior theory, our focus is on theory development. In addition, the ability of PLS to model formative as well as reflective constructs makes it suitable for our purposes.

Jarvis et al. (2003) note that the decision to model a construct as formative or reflective should be based on four major criteria: (1) direction of causality from construct to indicators, (2) interchangeability of indicators, (3) covariation among indicators, and (4) nomological net of construct indi-

\footnotetext{
${ }^{6}$ The analysis was done using PLS Graph 3.00.
} 
Table 2. Measurement of Constructs

\begin{tabular}{|c|c|c|c|c|}
\hline Latent Construct & Type & Sub-Construct & Type & $\begin{array}{l}\text { Number of } \\
\text { items }\end{array}$ \\
\hline \multirow{2}{*}{$\begin{array}{l}\text { IT Infrastructure } \\
\text { Integration for SCM }\end{array}$} & \multirow[b]{2}{*}{ Formative } & Data Consistency & Formative & 3 \\
\hline & & $\begin{array}{l}\text { Cross-functional SCM Application } \\
\text { Integration }\end{array}$ & Formative & 4 \\
\hline \multirow{3}{*}{$\begin{array}{l}\text { Supply Chain } \\
\text { Process Integration }\end{array}$} & \multirow{3}{*}{ Formative } & Information Flow Integration & Formative & 5 \\
\hline & & Physical Flow Integration & Formative & 4 \\
\hline & & Financial Flow Integration & Formative & 2 \\
\hline \multirow{3}{*}{ Firm Performance } & \multirow{3}{*}{ Formative } & Operations Excellence & Formative & 3 \\
\hline & & Customer Relationship & Formative & 2 \\
\hline & & Revenue Growth & Formative & 2 \\
\hline
\end{tabular}

cators. Constructs should be modeled as formative if the following decision rules hold: the direction of causality is from indicators to constructs, the indicators need not be interchangeable, covariation among indicators is not necessary; and the nomological net of indicators can differ. They should be modeled as reflective if the opposite conditions apply. For the three second-order constructs and each of their subconstructs in our research model, these decision rules suggest to us that the constructs should be modeled as formative. Table 2 summarizes the constructs and sub-constructs and the number of indicators associated with each sub-construct.

The first stage of data analysis focused on measurement properties of constructs. We assessed convergent and discriminant validity by factor analyzing items grouped under a second-order construct (i.e., IT infrastructure integration for SCM, supply chain process integration, and firm performance). The expected factor structure was obtained in all three cases (see Appendix A). We also examined the itemtotal correlations for these constructs (see Appendix B). The correlation pattern indicates that an item posited to form a given sub-construct has a stronger correlation with it than another construct providing further evidence of discriminant and convergent validity.

Another suggested criterion for discriminant validity is that the variance shared by a construct with its indicators should be greater than the variance shared with other constructs in the model. Fornell and Larcker (1981) note that average variance extracted can be used to assess the variance shared between the construct and its measurement items. Table 3 provides the results of this analysis. A construct is considered to be distinct from other constructs if the square root of the average variance extracted for it is greater than its correlations with other latent constructs (Barclay et al. 1995), which is observed to be the case.

To further investigate the pattern of association among formative indicators, internal consistency of sub-constructs was assessed using Cronbach's alpha and Fornell and Larcker's measure of composite reliability. Based on Nunnally's (1978) guidelines, a score of 0.70 or above is an acceptable value of internal consistency for exploratory research. While the constructs meet tests of internal consistency and convergent validity in our empirical context, it should be emphasized that these are not necessary requirements for formative constructs (Jarvis et al. 2003). The collective evidence suggests that the constructs demonstrate good measurement properties.

Subsequently, we created linear composites from the items used to measure each sub-construct and used them as formative indicators for the latent constructs specified in the structural model. Factor scores or multivariate means can be used to compute linear composite scores. The multivariate mean is based on the summated mean values of items and offers the advantages of being replicable across samples. It is the recommended approach when new measures are developed and transferability is desired (Hair et al. 1995). Rozeboom (1979) also notes that linear composite scores based on different weighting schemes are highly correlated when the items are internally consistent, which is true in our case. Thus, while internal consistency is not a requirement for formative constructs, linear composite scores, which were computed using different estimation methods for indicator weights, were found to be highly correlated for each subconstruct. Consequently, the use of these different linear composite scores did not change the observed pattern of relationships reported below. 
Table 3. Assessment of Discriminant Validity

\begin{tabular}{|l|c|c|c|c|c|c|c|c|c|c|c|}
\multicolumn{1}{|c|}{ Constructs } & $\begin{array}{c}\text { Mean } \\
\text { (SD) }\end{array}$ & DC & CAI & FFI & PFI & IFI & OE & RG & CR & CD & SZ \\
\hline Data Consistency (DC) & $\begin{array}{c}.40 \\
(.24)\end{array}$ & .76 & & & & & & & & & \\
\hline $\begin{array}{l}\text { Cross-Functional Application } \\
\text { Systems Integration (CAI) }\end{array}$ & $\begin{array}{c}.47 \\
(.24)\end{array}$ & .53 & .80 & & & & & & & & \\
\hline $\begin{array}{l}\text { Financial Flow } \\
\text { Integration (FFI) }\end{array}$ & $\begin{array}{c}.31 \\
(.22)\end{array}$ & .21 & .23 & .78 & & & & & & & \\
\hline $\begin{array}{l}\text { Physical Flow } \\
\text { Integration (PFI) }\end{array}$ & $\begin{array}{c}.52 \\
(.21)\end{array}$ & .36 & .26 & .25 & .67 & & & & & & \\
\hline Information Flow \\
Integration (IFI) & $\begin{array}{c}.49 \\
(.20)\end{array}$ & .55 & .40 & .20 & .53 & .73 & & & & & \\
\hline Operational Excellence (OE) & $\begin{array}{c}.34 \\
(.16)\end{array}$ & .29 & .23 & .24 & .28 & .31 & .76 & & & & \\
\hline Revenue Growth (RG) & .38 & .15 & .14 & -.04 & .31 & .29 & .25 & .83 & & & \\
\hline Customer Relationship (CR) & $\begin{array}{c}.31 \\
(.18)\end{array}$ & .17 & .13 & .14 & .33 & .16 & .40 & .31 & .84 & & \\
\hline $\begin{array}{l}\text { Consumer Demand } \\
\text { Predictability (CD) }\end{array}$ & $\begin{array}{c}.44 \\
(.17)\end{array}$ & .30 & .14 & .03 & .14 & .09 & -.00 & -.03 & .07 & .80 & \\
\hline Firm Size (SZ) & $\begin{array}{c}19.08 \\
(39.80)\end{array}$ & -.10 & -.02 & -.00 & -.05 & -.06 & .00 & .11 & .05 & -.21 & NA \\
\hline
\end{tabular}

${ }^{*}$ The shaded diagonal values are the square root of the average variance extracted for each construct. Firm size is in thousands of employees.

\section{Results}

Each second-order latent construct is modeled as a formative construct consisting of its sub-constructs as indicators. As the interpretation of the weights is similar to the beta coefficients in a standard regression model, it is usual to have lower absolute weights as compared to loadings. The PLS method does not directly provide significance tests and confidence interval estimates of path coefficients in the research model. In order to estimate the significance of path coefficients, a bootstrapping technique was used. Bootstrap analysis was done with 500 subsamples and path coefficients were reestimated using each of these samples. The vector of parameter estimates was used to compute parameter means, standard errors, significance of path coefficients, indicator loadings, and indicator weights. This approach is consistent with recommended practices for estimating significance of path coefficients and indicator loadings (Löhmoeller 1984) and has been used in prior IS studies (Chin and Gopal 1995; Compeau and Higgins 1995; Howell and Higgins 1990; Ravichandran and Rai 2000).
Results of the analysis for the structural model are presented in Figure 3. No minimum threshold values for indicator weights have been established. The statistical significance of weights can be used to determine the relative importance of indicators in forming a latent construct. We found that all specified paths between constructs in our research model had significant path coefficients. In terms of the indicators, customer relationships and financial flow integration did not have significant formative weights for the firm performance and supply chain process integration constructs respectively. Finally, the two specified control variables were not found to be significantly associated with firm performance.

The results provide support for the research model. One indicator of the predictive power of path models is to examine the explained variance or $\mathrm{R}^{2}$ values (Barclay et al. 1995; Chin and Gopal 1995). $R^{2}$ values are interpreted in the same manner as those obtained from multiple regression analysis. They indicate the amount of variance in the construct that is explained by the path model (Barclay et al. 1995). The results indicate that the model explained 18.6 percent of the variance 


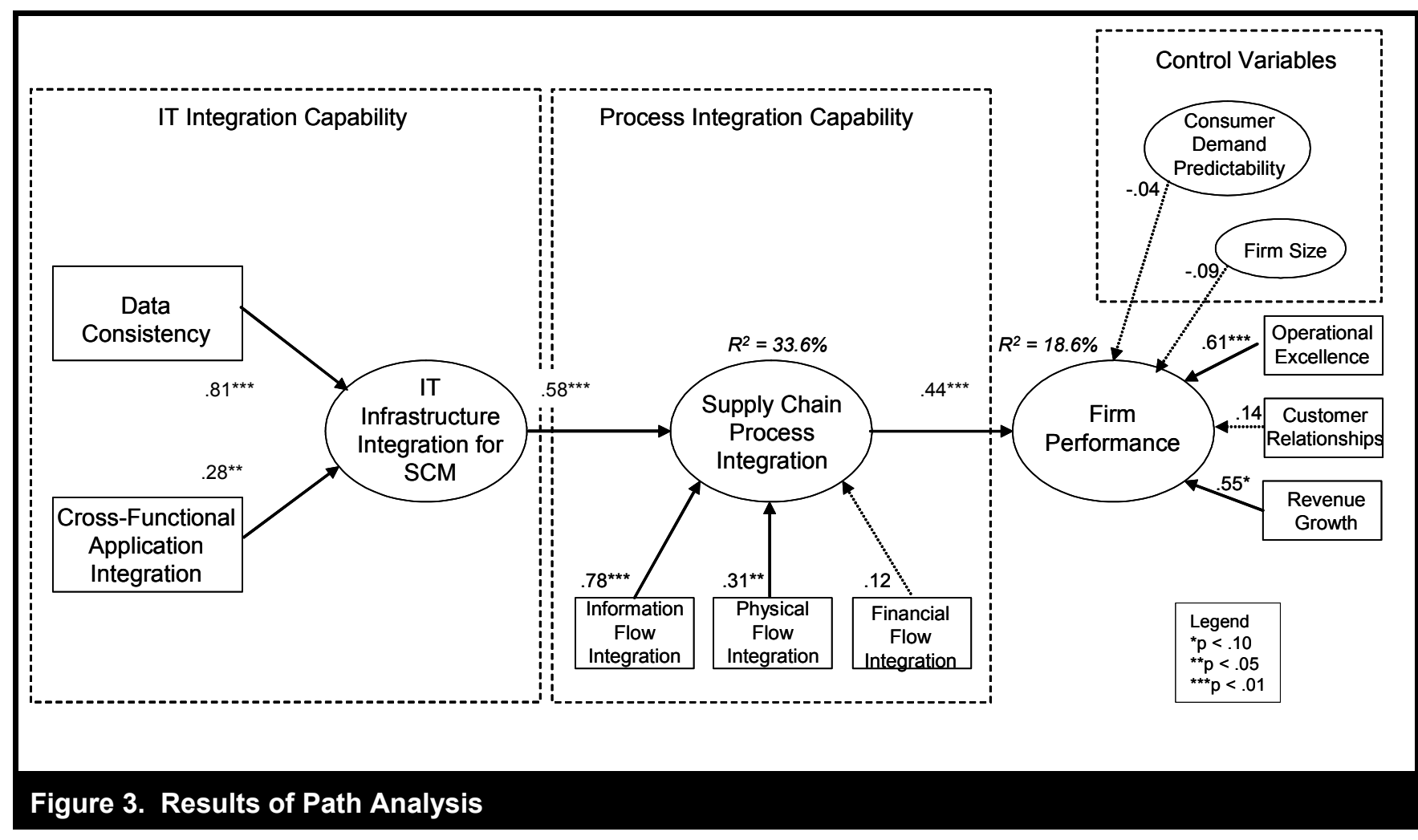

in firm performance. Similarly, 33.6 percent of the variance in supply chain process integration was explained by IT infrastructure integration. The path coefficient from IT infrastructure integration to supply chain process integration was .58 and from supply chain process integration to firm performance was .44. The magnitude and significance of these path coefficients provides additional evidence in support of the research model.

Since our model proposes that supply chain process integration mediates the impact of SCM-related IT infrastructure integration on firm performance, we tested the mediation effect in two ways. First we compared the research model that proposes full mediation against a competing model that proposed both direct and mediated effects (i.e., a partially mediated model of SCM-related IT infrastructure integration and firm performance). Since the models are nested, they can be compared statistically using PLS results (Chin et al. 2003; Subramani 2004). The partially mediated model has one more path (from IT infrastructure integration to firm performance) than the fully mediated research model. The $\mathrm{R}^{2}$ for firm performance in the partially mediated model was .197 as compared to .186 in the fully mediated research model. The effect of the extra path in the partially mediated model is assessed using a procedure similar to the one used to test competing models in stepwise linear regression. Accordingly, the $f^{2}$ statistic, which is based on the difference in $\mathrm{R}^{2}$ between the two models, was first computed and then used to compute the pseudo $F$ statistic. ${ }^{7}$ Based on the results of the two competing models for our sample, $f^{2}$ was .0136 and pseudo $\mathrm{F}$ $(1,106)$ statistic was 1.441 , which was insignificant. The analysis suggests that the additional variance explained by introducing the direct path from IT infrastructure integration to firm performance does not significantly add to the variance explained in the dependent variable.

In addition to comparing partial mediation with full mediation, we used mediation analysis techniques (Hoyle and Kenny 1999; Subramani 2004) to assess the significance of the mediation effect of supply chain process integration on the relationship between IT infrastructure integration and firm performance. The analysis is based on the path coefficients and the standard errors of the direct paths between IT infrastructure integration (independent variable, designated iv), supply chain process integration (mediating variable,

\footnotetext{
${ }^{7}$ The formula for computing $f^{2}$ is $\left(\mathrm{R}^{2}\right.$ partial mediation - $\mathrm{R}^{2}$ full mediation $) /\left(1-\mathrm{R}^{2}\right.$ partial mediation $)$. The pseudo $\mathrm{F}$ statistic is computed using the formula $f^{2} *(\mathrm{n}-\mathrm{k}-1)$, with $1,(\mathrm{n}-\mathrm{k})$ degrees of freedom where $\mathrm{n}$ is the sample size and $\mathrm{k}$ is the number of constructs in the model (Chin et al. 2003).
} 
designated $\mathrm{m}$ ), and firm performance (dependent variable, designated dv). The magnitude of mediation is computed as the product of the standardized path coefficients between IT infrastructure integration and supply chain process integration (iv $\rightarrow \mathrm{m}$ ) and between supply chain process integration and firm performance $(\mathrm{m} \rightarrow \mathrm{dv})$. The magnitude of mediation effect based on the PLS results was .259. The standard error of the mediated path is computed based on the standardized path coefficients and standard deviations of the direct paths among the independent, mediating, and dependent variable. ${ }^{8}$ The computations yield a $z$-statistic of 2.75 , which is significant at $\mathrm{p}<.01$. The two tests are considered as complementary test of mediation (Subramani 2004) as the nested model analysis assesses the additional explanatory power of competing models, while the mediation analysis provides information on the significance of mediation effects.

To validate our results obtained with subjective measures of firm performance, we replicated the analysis using applicable objective firm performance measures. We collated publicly available information about firm performance from COMPUSTAT with survey data for firms where respondents had provided us with requested identification information in their responses. This collation process resulted in a dataset with objective measures for 57 firms. We conducted multiple cross-validations to assess quality of survey data used to assess performance and test the model. First, the revenue data provided by survey respondents had a correlation of .92 with publicly reported revenue data, providing evidence of the accuracy of the respondents' estimates. We then computed a three-year mean value of inventory turns and net trade cycle, also referred to as a cash-cash conversion cycle. These two measures assess operational excellence and are suggested to be impacted by supply chain integration (Rai, Bush, and Tiwana 2002; Simchi-Levi et al. 2000; Supply-Chain Council 2003). The mean value and standard deviation for inventory turns were 8.05 and 10.36 turns per year, while the mean value and standard deviation for net trade cycle were 82.27 and 62.01 days respectively.

Since our survey assessed relative subjective performance of the firm, we computed a difference between the three-year mean value of inventory turns and net trade cycle for each firm from the mean values within the two-digit SIC category. We again evaluated the research model using PLS with these computed measures of relative superiority of a firm for inventory turns and net trade cycle. The indicators were

\footnotetext{
${ }^{8} \mathrm{An}$ approximation for the standard error of the mediated path is computed using the formula $\operatorname{sqrt}\left(\mathrm{p}_{1}{ }^{2} \mathrm{~s}_{2}{ }^{2}+\mathrm{p}_{2}{ }^{2} \mathrm{~s}_{1}{ }^{2}+\mathrm{s}_{1}{ }^{2} \mathrm{~s}_{2}{ }^{2}\right)$ where $\mathrm{p}_{1}$ is the path coefficient of the path from iv $\rightarrow \mathrm{m}$ and $\mathrm{p}_{2}$ is the path coefficient from $\mathrm{m} \rightarrow \mathrm{dv}$ and $\mathrm{s}_{1}$, $\mathrm{S}_{2}$ are the corresponding standard deviations (Hoyle and Kenny 1999).
}

modeled as reflective since the two measures of operational excellence are expected to covary. The significant paths are replicated, and the model explains 12.3 percent of the variance in operational excellence assessed by relative performance superiority using objective measures of inventory turns and net trade cycle. Triangulation of results using crossvalidation analyses with relative objective measures of operational excellence for a firm provides additional support for the validity of the subjective performance measures collected by means of the survey and of the observed path relationships between constructs.

\section{Discussion}

The results suggest that IT infrastructure integration for SCM enables supply chain process integration, which in turn yields sustained gains in firm performance, particularly operational excellence and revenue growth. These findings have significant implications for the management of IT infrastructure integration, as it needs to be focused and leveraged to create performance gains by using lower-order technology capabilities to enable higher-order process integration capabilities.

\section{Integrated IT Infrastructure for SCM}

Past framings of IT infrastructure identify reach and range as important business functionalities enabled by IT infrastructure platforms (Broadbent et al. 1999; Keen 1991). Reach refers to the connectivity of the IT infrastructure, while range refers to the variety of information resources that can be exchanged by the IT infrastructure. In the context of SCM, crossfunctional applications integration enables near real-time connectivity across a range of complementary applications focused on planning and execution, and their connectivity with applications for enterprise resource planning and customer relationship management. Having common data definitions and data consistency not only enables connectivity across the supply chain, but also enables the exchange of complementary information between a firm and its supply chain partners.

Drawing on the resource-based view of the firm, Bharadwaj (2000) expanded our conceptualization of IT-based resources to include IT infrastructure, human IT resources, and ITenabled intangible processes. She notes the limitations to conceptualizing IT infrastructure as a lower-level tangible physical resource, which, by definition, is more likely to be mimicked by competition. Instead, an integrated IT infrastructure represents a capability that is not easily mimicked as 
it is established through a combination of lower-level tangible resources and complementary intangible and human IT resources.

Our results provide evidence that IT infrastructure integration targeted at SCM enables the transformation of fragmented, functional, silo-oriented supply chain processes to integrated, cross-functional, interfirm supply chain processes. The latter are characterized by synergies derived from integrating resource flows between a firm and its supply chain partners. An inspection of the weights associated with the two formative indicators (i.e., data consistency and cross-functional SCM application integration) suggest that both are critical elements of IT infrastructure integration in this context. However, data consistency is relatively more important, in comparison to cross-functional application integration, suggesting the high degree of importance of data quality and standards as facilitators of process integration.

\section{Supply Chain Process Integration as an IT-Enabled Process Capability}

Our results indicate that a firm's IT-based platform capabilities have a substantial effect on supply chain process integration. This capability is deeply embedded into the structure of interfirm operational processes, such as order management, inventory management, logistics, and distribution; financial processes, such as billing and receivables management; and information processes, such as demand planning and forecasting. The integration associated with these processes is achieved through a series of initiatives that may include trading partner agreements and supply chain partnerships in addition to the deep embedding of integrated IT capabilities as process enablers. The development of process integration capability that leverages IT infrastructure integration requires substantial expertise spanning the business process domain, partnership context, and IT. This capability development requires significant time, making rapid imitation by competition difficult.

Our results suggest that supply chain process integration fully mediates the impact of IT infrastructure integration on firm performance. Information flow integration has the largest effect on the formation of supply chain process integration capability, followed by physical flow integration, with financial flow integration having an insignificant impact. We observed that the mean value for financial flow integration was relatively high (3.8 on a scale from 1 to 7$)$ and, more notably, its variance somewhat low (1.01). Automatic invoicing and payment systems appear to have been implemented and access to these capabilities is made much easier through the marketplace. As a result, while these capabilities are increasingly a prerequisite for transacting financially, they do not contribute to the explanation of variance in firm performance. More sophisticated measures of financial flow integration that capture variance in this capability across firms need to be incorporated in future studies.

A good illustration of the powerful and sustainable impact of supply chain process integration is Dell's virtual integration model, which has contributed to the firm's market position and sustained advantage. Dell's supply chain process integration capability is hard to imitate, as evidenced by the unsuccessful mimetic behavior of its competition for several years. Other relationship management resources and capabilities, such as trust between partners, colocated assets, and collaborative incentive systems and interaction routines, are likely required complements of IT infrastructure integration capabilities for supply chain process integration. Future research should investigate these complementarities so that both IT infrastructure integration and relationship management capabilities are effectively leveraged for supply chain process integration.

\section{Leveraging Synergies among Integrated Flows for Performance Gains}

Our results indicate that operational excellence has a very strong and significant weight in the formation of the firm performance construct. The strong effect of supply chain process integration on firm performance, as indicated by the path coefficient, suggests that supply chain process integration improves operational performance relative to competition by squeezing out delays, redundant tasks, and inefficient flows. The strong effect on revenue growth also suggests that supply chain process integration enables market penetration and provides the agility to ensure that sales opportunities associated with the launch of new products and entry into new markets are captured. The insignificant weight of customer relationships with firm performance suggests that supply chain process integration may not directly lead to superior customer relationships, but that such gains may occur through customer relationship management initiatives.

\section{Disaggregated Specification of Firm Performance in the Capabilities- Performance Nomology}

It has been suggested that operational performance impacts other key aspects of firm performance (Barua et al. 2001; 
Mukhopadhyay et al. 1995). Accordingly, we disaggregated the indicators of firm performance in our model to investigate the impact of operational excellence on revenue growth and customer relationships. The first disaggregated model examined if supply chain process integration improves operational excellence, which, in turn, improves revenue growth and customer relationships. The second disaggregated model examined if supply chain process integration improves relative inventory turnover performance (objective measure), which, in turn, improves revenue growth and customer relationships. Finally, the third disaggregated model examined if supply chain process integration improves relative net trade cycle (objective measure), which, in turn, improves revenue growth and customer relationships. For the second and third disaggregated models, the reduced subsample of 57 firms with objective measures for inventory turnover and net trade cycle was used. In each case, all paths from the IT infrastructure integration to supply chain process integration are significant. In addition, in each case, supply chain process integration had a significant impact on the measure of operational performance considered (subjective measure of operational excellence $\left[R^{2}=12.7 \%\right]$, relative inventory turnover $\left[R^{2}=8.5 \%\right]$, and relative net trade cycle $\left[R^{2}=9 \%\right]$ ), which, in turn, significantly impacted revenue growth and customer relationships. These results support the suggestion that supply chain process integration has a direct impact on operational performance, which, in turn, leads to improvements in other key aspects of firm performance, such as customer relationships and revenue growth.

\section{Contingency Considerations for Supply Chain Process Integration}

The results indicate that supply chain process integration has a significant impact on firm performance, specifically operational excellence and revenue growth. We caution that a limited focus on optimization of operational costs without regard to building in buffers for demand and supply uncertainty can have detrimental consequences on service levels and response times (Lee 2002). For example, in the case of supply chain process integration for the movement of configure-to-order products from source of supply to consumption, it is important to position component-level stocks strategically so that product configuration and assembly can be postponed until the order is specified by the customer. Companies are modularizing product designs and developing their information sharing capabilities as part of their transitions from a build-to-stock fulfillment model to a configureto-order fulfillment model (Simchi-Levi and Simchi-Levi 2001). While integrated flows are critical to both fulfillment approaches, a sole focus on operational costs without a welldefined component-level buffer strategy is likely to be detrimental when final consumer demand is hard to predict. Differences in supply chain process integration capabilities needed for different levels of demand and supply uncertainties are fruitful areas for future research.

\section{Limitations and Future Research}

We hope that our study triggers a series of related investigations by the IS research community. There are specific limitations to our work. First, the unit of analysis of this study is not a specific supply chain for a given product line but a focal firm. We examine aggregate IT-enabled supply chain capabilities across the primary products for a firm. This results in aggregation across supply chains for products. On the other hand, this unit of analysis allows us to focus on broader organization-wide patterns of IT infrastructure integration, supply chain process integration, and firm performance. This enables a clear and identifiable linkage with measures of firm performance. Second, the study focused on manufacturing and retail organizations and collected data from member firms of the Council for Logistics Management. As such, the model and relationships should be examined in other industrial sectors and from a broader representation of firms in the manufacturing and retail sectors. Third, variables such as structure of specific supply chains, number of tiers in the chain, types of supply chain applications, and types of business processes integrated, which have not been examined, should help us develop a better understanding of IT-enabled supply chain capabilities in different contexts. Fourth, our measure of financial flow integration focused on event-based integration of receivables and payables; more complex patterns of financial flow integration that can be supported by IT should be explored. Fifth, subjective measures of the key respondent are used for firm performance, albeit the results are replicated with important objective measures of firm performance. Future studies need to include other objective measures of firm performance.

Most constructs used in the study have been developed for the first time and the nature of the relationships investigated is exploratory. Future studies need to investigate the relationship between physical, financial, and information flow integration, the complementarities between them, and their differential impact on firm performance in business environments characterized by different demand patterns for products and services. In addition, the role of complementary organizational capabilities, such interorganizational relational capabilities, need to be explored in terms of their impact on supply chain process integration and firm performance. 
To the degree that future research integrates additional concepts pertaining to uncertainties in the demand and supply environment and strategic choices with respect to supplier relationships, we will start developing theoretical linkages between important concepts in information systems, strategy, and operations as they relate to SCM. As IT infrastructure capabilities are deployed to architect business networks, the development of such interdisciplinary theoretical understanding is critical and represents a huge opportunity for IS researchers.

\section{Concluding Remarks}

We defined a hierarchy of capabilities to develop the theoretical linkages between IT infrastructure integration, supply chain process integration, and firm performance. Our results suggest that IT infrastructure integration capability for SCM requires data consistency and cross-functional application integration, with data consistency being relatively more important. IT infrastructure integration capability must be leveraged by a focal firm to develop higher-order supply chain process integration capabilities that create performance gains. This higher-order boundary-spanning capability requires the sharing of strategic, tactical, and operational information and global optimization of physical flows across supply chains. Development of supply chain process integration capability positions firms to realize improvements in their performance, specifically operational excellence and increased revenues.

\section{Acknowledgments}

We thank the senior editor, associate editor, and reviewers for their constructive comments during the review process.

\section{References}

Anderson, J. C., Hakansson, H., and Johanson, J. “Dyadic Business Relationships Within a Network Context," Journal of Marketing (58:4), 1994, pp. 1-15.

Armstrong, J., and Overton, T. "Estimating Non-response Bias in Mail Surveys," Journal of Marketing Research (14:3), 1977, pp. 396-402.

Arntzen, B. C., Brown, G. G., Harrison, T. P., and Trafton, L. "Global Supply Chain Management at Digital Equipment Corporation," Interfaces (25:1), 1995, pp. 69-93.

Barclay, D., Higgins, C., and Thomson, R. "The Partial Least Squares Approach to Causal Modeling, Personal Computer
Adoption and Use as an Illustration," Technology Studies (2:2), 1995, pp. 285-309.

Barney, J. B. "Firm Resources and Sustained Competitive Advantage," Journal of Management (17:1), 1991, pp. 99-120.

Barua, A., Konana, P., Whinston, A. B., and Yin, F. "Assessing Net-Enabled Business Value: An Exploratory Analysis," MIS Quarterly (28:4), 2004, pp. 585-620.

Barua, A., Whinston, A., Konnana, P., and Fang, Y. "Driving EBusiness Excellence," Sloan Management Review, Fall 2001, pp. 36-44.

Bharadwaj, A. "A Resource-Based Perspective on Information Technology Capabilities and Firm Performance: An Empirical Investigation," MIS Quarterly (24:1), 2000, pp. 169-196.

Black, J. T. The Design of the Factory with a Future, McGraw Hill, New York, NY, 1991.

Broadbent, M., Weill, P., and St. Clair, D. "The Implications of Information Technology Infrastructure for Business Process Redesign,” MIS Quarterly (23:2), 1999, pp. 159-182.

Carlile, P. R. "A Pragmatic View of Knowledge and Boundaries: Boundary Objects in New Product Development," Organization Science (13:4), 2002, pp. 442-455.

Chin, W. W., and Gopal, A. "Adoption Intention in GSS: Relative Importance of Beliefs," The Data Base for Advances in Information Systems (26:2\&3), 1995, pp. 42-63.

Chin, W. W., Marcolin, B. L., and Newstead, P. R. "A Partial Least Squares Latent Variable Modeling Approach for Measuring Interaction Effects: Results from a Monte Carlo Simulation Study and an Electronic-Mail Emotion/ Adoption Study," Information Systems Research (14:2), 2003, pp. 189-217.

Cohen, M. A., and Lee, H. L. "Strategic Analysis of Integrated Production-Distribution Systems: Models and Methods," Operations Research (36:2), 1998, pp. 216-228.

Compeau, D. R., and Higgins, C. A. "Computer Self-Efficacy: Development of a Measure and Initial Test," MIS Quarterly (19:2), 1995, pp. 189-211.

Cronbach, L. J. "Test Validation in Education Measurement," in Educational Measurement ( $2^{\text {nd }}$ ed.), R. L. Thorndike (ed.), American Council on Education, Washington, DC, 1971, pp. 443-507.

Daugherty, P. J., Myers, M. B., and Autry, C. W. "Automatic Replenishment Programs," Journal of Business Logistics (20:2), 1999, pp. 63-82.

Dess, G. "Consensus on Strategy Formulation and Organizational Performance: Competitors in a Fragmented Industry," Strategic Management Journal (8:3), 1987, pp. 259-277.

Ellinger, A. E., Taylor, J. C., and Daugherty, P. J. "Automatic Replenishment Programs and Level of Involvement: Performance Implications," The International Journal of Logistics Management (10:1), 1999, pp. 25-36.

Enslow, B. "Internet Fulfillment: The Next Supply Chain Frontier," Achieving Supply Chain Excellence through Technology (ASCET) (2), Montgomery Research, Inc., San Francisco, CA, April 15, 2000 (available online at http://www.ascet.com/ documents.asp?d_ID=278). 
Feitzinger, E., and Lee, H. L. "Mass Customization at Hewlett Packard: The Power of Postponement," Harvard Business Review (75:1), January-February 1997, pp. 116-121.

Fields, G. "The Internet and the Production Network of Dell Computer," Part III in From Communications and Innovation to Business Organization and Territory: The Production Networks of Swift Meat Packing and Dell Computer, Working Paper 149, BRIE, Berkeley, CA, March 2003 (available online at http:// brie.berkeley.edu/ briewww/publications/working_papers.html).

Fisher, M. L. "What Is the Right Supply Chain for Your Product," Harvard Business Review (75:2), March-April 1997, pp. 105-116.

Floyd, S., and Wooldridge, B. "Path Analysis of the Relationship Between Competitive Strategy, Information Technology, and Financial Performance," Journal of Management Information Systems (7:1), 1990, pp. 47-64.

Fornell, C., and Larcker, D. "Evaluating Structural Equation Models with Unobservable Variables and Measurement Error," Journal of Marketing Research (18:1), 1981, pp. 39-50.

Geoffrion, A. M., and Powers, R. F. "Twenty Years of Strategic Distribution System Design: An Evolutionary Perspective," Interfaces (25:5), 1995, pp. 105-127.

Goldhar, J. D., and Lei, D. "The Shape of Twenty-First Century Global Manufacturing," The Journal of Business Strategy (12:2), 1991, pp. 37-41.

Grant, R. "Prospering in Dynamically-Competitive Environments: Organizational Capability as Knowledge Integration," Organization Science (7:4), 1996, pp. 375-387.

Greenfield, A., Patel, J., and Fenner, J. "Online Invoicing for Business-to-Business Users," Information Week (863), November 12, 2001, pp. 80-82.

Groves, G., and Valsamakis, V. "Supplier-Customer Relationships and Company Performance," International Journal of Logistics Management (9:2), 1998, pp. 51-64.

Gustin, C. M., Daugherty, P. J., and Stank, T. P. "The Effects of Information Availability on Logistics Integration," Journal of Business Logistics (16:1), 1995, pp. 1-12.

Hagel, J., and Singer, M. "Unbundling the Corporation," Harvard Business Review (77:2), 1999, pp. 133-141.

Hair, J. F., Anderson, R. E., Tatham, R. L., and Black, W. C. Multivariate Data Analysis ( $4^{\text {th }}$ ed.), Prentice Hall, Engelwood Cliffs, NJ, 1995.

Hammer, M. "Reengineering Work: Don't Automate, Obliterate," Harvard Business Review (68:4), 1990, pp. 104-114.

Hitt, L. M., Wu, D. J., and Xiaoge, Z. "Investment in Enterprise Resource Planning: Business Impact and Productivity Measures," Journal of Management Information Systems (19:1), 2002.

Ho, D. C. K., Au, K. F., and Newton, E. "Empirical Research on Supply Chain Management: A Critical Review and Recommendations," International Journal of Production Research (40:17), May 2002, pp. 4415-4430.

Howell, J. M., and Higgins, C. A. "Champions of Technological Innovation," Administrative Science Quarterly (35:2), 1990, pp. 317-341.

Hoyle, R. H., and Kenny, D. A. "Statistical Power and Tests of Mediation," in Statistical Strategies for Small Sample Research,
D. A. Kenny (ed.), Sage Publications, Newbury Park, CA, 1999, pp. 195-222.

Huber, G. "A Theory of the Effects of Advanced Information Technologies on Organizational, Design, Intelligence, and Decision Making," Academy of Management Review (15:1), 1990, pp. 47-71.

Hult, G. T., Ketchen, D. J., and Slater, S. F. "Information Processing, Knowledge Development, and Strategic Supply Chain Performance," Academy of Management Journal (47:2), 2004, pp. 243-253.

Jarvis, C. B., Mackenzie, S. B., and Podsakoff, P. M. “A Critical Review of Construct Indicators and Measurement Model Misspecification in Marketing and Consumer Research," Journal of Consumer Research (30:2), 2003, pp. 199-218.

Jöreskog, K. G., and Wold, H. "The ML and PLS Techniques for Modeling with Latent Variables: Historical and Comparative Aspects," in Systems Under Indirect Observation: Causality Structure and Prediction, K. G. Jöreskog and H. Wold (eds.), North Holland, Amsterdam, 1982, pp. 263-270.

Kaeli, J. K. "A Company-Wide Perspective to Identify, Evaluate, and Rank the Potential for CIM," Industrial Engineering (22:7), 1990, pp. 23-26.

Kalakota, R., and Robinson, M. E-Business: Roadmap for Success, Addison-Wesley, Reading, MA, 1999.

Kalwani, M. U., and Naravandas, N. "Long-Term Manufacturer Supplier Relationships-Do They Pay Off for Supplier Firms," Journal of Marketing (59:1), 1995, pp. 1-16.

Keen, P. G. W. Shaping the Future: Business Design through Information Technology, Harvard Business School Press, Cambridge, MA, 1991.

Kerlinger, F. N. Foundations of Behavioral Research, Rinehart \& Winston, New York, 1986.

Lawrence, P., and Lorsch, J. Organization and Environment: Managing Differentiation and Integration, Irwin, Homewood, IL, 1967.

Lee, H. L. "Aligning Supply Chain Strategies with Product Uncertainties," California Management Review (44:3), 2002, pp. 105-115.

Lee, H. L. "Creating Value through Supply Chain Integration," Supply Chain Management Review (4:5), 2000, pp. 30-36.

Lee, H. L., and Billington, C. "Managing Supply Chain Inventory: Pitfalls and Opportunities," Sloan Management Review (33:3), 1992, pp. 65-75.

Lee, H. L., Padmanabhan, V., and Whang, S. "Information Distortion in Supply Chain: The Bullwhip Effect," Management Science (43:4), 1997, pp. 546-558.

Lee, H. L., So, K., and Tang, C. "The Value of Information Sharing in a Two-Level Supply Chain," Management Science (46:5), 2000, pp. 626-643.

Lee, H. L., and Whang, S. "Information Sharing in a Supply Chain," Working Paper, Research Paper Series, Graduate School of Business, Stanford University, July 1998.

Löhmoeller, J. B. LVPS 1.6 Program Manual: Latent Variable Path Analysis with Partial Least Squares Estimation, Universitaet zu Koehn, Zentralarchiv fuer Empirische Sozialforschung, 1984. 
Lowson, B., King, R., and Hunter, A. Quick Response: Management of the Supply Chain to Meet Consumer Demand, John Wiley \& Sons, London, 1999.

Mabert, V. A., and Venkatraman, M. A. "Special Research Focus on Supply Chain Linkages: Challenges for Design and Management in the 21st Century," Decision Sciences (29:3), 1998, pp. 537-550.

Magretta, J. "The Power of Virtual Integration: An Interview with Dell Computer's Michael Dell," Harvard Business Review (76:2), March/April 1998, pp. 72-84.

Malhotra, A., Gosain, S., and El Sawy, O. A. "Absorptive Capacity Configurations in Supply Chains: Gearing for Partner-Enabled Market Knowledge Creation," MIS Quarterly (29:1), 2005, pp. 145-187.

Malone, T. W., Yates, J., and Benjamin, R. I. "Electronic Markets and Electronic Hierarchies," Communications of the ACM(30:6), 1987, pp. 484-497.

McCormack, K. P., and Johnson, W. C. Supply Chain Networks and Business Process Orientation, St. Lucie Press, Boca Raton, FL, 2003.

Milgrom, P., and Roberts, J. "Communication and Inventory as Substitutes in Organizing Production," Scandinavian Journal of Economics (90), 1988, pp. 93-105.

Mithas, S., Ramasubbu, N., Krishnan, M. S., and Sambamurthy, V. "Information Technology Infrastructure Capability and Firm Performance: An Empirical Analysis," Working Paper, Ross School of Business, University of Michigan, 2004.

Mohr, J., and Nevin, J. R. "Communication Strategies in Marketing Channels: A Theoretical Perspective," Journal of Marketing (54:4), 1990, pp. 36-51

Moorman, C. "Organizational Market-Information Processes: Cultural Antecedents and New Product Outcomes," Journal of Marketing Research (32:3), 1995, pp. 318-335.

Mukhopadhyay, T., Kekre, S., and Kalathur, S. "Business Value of Information Technology: A Study of Electronic Data Interchange," MIS Quarterly (19:2), June 1995, pp. 137-156.

Narsimhan, R., and Jayram, J. "Causal Linkages in Supply Chain Management: An Exploratory Study of North American Manufacturing Firms," Decision Sciences (29:3), 1998, pp. 579-605.

Nunnally, J. C. Psychometric Theory, McGraw-Hill, New York, 1978.

Pitoura, E., and Bhargava, B. "Data Consistency in Intermittently Connected Distributed Systems," IEEE Transactions on Knowledge and Data Engineering (11:6), 1999, pp. 896-915.

Powell, T. "Organizational Alignment as Competitive Advantage," Strategic Management Journal (13:2), 1992, pp. 119-134.

Powell, T. C., and Dent-Micallef, A. "Information Technology as Competitive Advantage: The Role of Human, Business, and Technology Resources," Strategic Management Journal (18:5), 1997, pp. 375-405.

Rai, A., Bush, A., and Tiwana, A. "Adaptive Planning and Optimization for Supply Chain Networks," White Paper, University Thought Leadership Forum on Adaptive Supply Chain Networks, SAP, 2002 (available online at http://www.vendor-showcase. com/Vendors/221/SAP_AdaptPlanning-10-2-02b.pdf; accessed November 14, 2005).
Rai, A., Ruppel, C., and Lewis, M. "Sense and Respond," White Paper, University Thought Leadership Forum, SAP, 2002 (available online at http://www.vendor-showcase.com/Vendors/ 221/SAP_Sense-Respond-10-2-02b.pdf; accessed November 14, 2005).

Rai, A., and Sambamurthy, V. “Adaptive Distribution Networks," White Paper, University Thought Leadership Forum on Adaptive Supply Chain Networks, SAP, 2002 (available online at http://www.vendor-showcase.com/Vendors/221/SAP Distribution-10-2-02b.pdf; accessed November 14, 2005).

Ravichandran, T., and Rai, A. "Quality Management in Systems Development: An Organizational Systems Perspective," MIS Quarterly (24:3), 2000, pp. 381-415.

Rayport, J. F., and Sviokla, J. J. "Exploiting the Virtual Value Chain," Harvard Business Review (73:6), November-December 1995, pp. 75-85.

Richardson, H. L. “Optimize Your Distribution Network," Transportation and Distribution (40:12), 1999, pp. 66-70.

Ross, J. W. "Creating a Strategic IT Architecture Competency: Learning in Stages," MIS Quarterly Executive (2:1), 2003, pp. 31-43.

Rozeboom, W. W. "Sensitivity of a Linear Composite Predictor Items to Differential Item Weighting," Psychometrica (44:3), 1979, pp. 289-296.

Sabath, R. E., and Frentzel, D. G. "Go for Growth: Supply Chain Management's Role in Growing Revenues," Supply Chain Management Review (1:2), Summer 1997, pp. 16-24.

Sahin, F., and Powell, R. E. "Flow Coordination and Information Sharing in Supply Chains: Review, Implications and Directions for Future Research," Decision Sciences (33:4), 2002, pp. 505-536.

Sambamurthy, V., Bharadwaj, A., and Grover, V. "Shaping Agility through Digital Options: Reconceptualizing the Role of IT in Contemporary Firms," MIS Quarterly (27:2), 2003, pp. 237-263.

Schneidrjans, M. J. Topics in Just-in-Time Management, Allyn \& Bacon, Needam Heights, MA, 1993.

Scott, C., and Westbrook, R. "New Strategic Tools for Supply Chain Management," International Journal of Physical Distribution \& Logistics Management (21:1), 1991, pp. 23-33.

Seidmann, A., and Sundarajan, A. "Building and Sustaining Interorganizational Information Sharing Relationships: The Competitive Impact of Interfacing Supply Chain Operations in Marketing Strategy," in Proceedings of the $18^{\text {th }}$ International Conference on Information Systems, K. Kumar and J. I. DeGross (eds.), Atlanta, GA, 1997, pp. 205-222.

Sethi, V., and King, W. R. "Construct Measurement in Information Systems Research: An Illustration in Strategic Systems," Decision Sciences (22:3), 1991, pp. 455-472.

Simchi-Levi, D., Kaminsky P., and Simchi-Levi, E. Designing and Managing the Supply Chain: Concepts, Strategies, and Case Studies, Irwin/McGraw-Hill, New York, 2000.

Simchi-Levi, D., and Simchi-Levi, E. "The Dramatic Impact of the Internet on Supply Chain Strategies," Achieving Supply Chain Excellence through Technology (ASCET) (3), Montgomery Research, Inc., San Francisco, CA, April 15, 2001 (available online at http://www.ascet.com/ documents.asp?d_ID=478). 
Slywotzky, A. J., Morrison, D. J., and Weber, K. How Digital Is Your Business?, Crown Business, New York, 2000.

Srinivasan, K., and Kekre, S. "Impact of Electronic Data Interchange Technology on JIT Shipments.," Management Science (40:10), 1994, pp. 1291-1294.

Stevens, G. C. "Successful Supply Chain Management," Management Decision (28:8), 1990, pp. 25-30.

Straub, D. "Validating Instruments in MIS Research," MIS Quarterly (13:2), 1989, pp. 147-169.

Subramani, M. R. "How Do Suppliers Benefit from Information Technology Use in Supply Chain Relationships?," MIS Quarterly (28:1), 2004, pp. 45-73.

Teece, D. J., Pisano, G., and Shuen, A. "Dynamic Capabilities and Strategic Management," Strategic Management Journal (18:7), 1997, pp. 509-533.

Turner, J. R. "Integrated Supply-Chain Management: What's Wrong with This Picture?," Industrial Engineering (25:12), 1993, pp. 52-55.

Tyndall, G. P., Gopal, C., Partsch, W., and Kamauff, J. W. Supercharging Supply Chains: New Ways to Increase Value through Global Operational Excellence, John Wiley \& Sons, New York, 1998.

van Hoek, R. I. "The Role of Third Party Logistics Providers in Mass Customization," The International Journal of Physical Distribution and Logistics Management (11:1), 2000, pp. 37-46.

Vidal, C., and Goetschalckx, M. "Modeling the Impact of Uncertainties on Global Logistics Systems," Journal of Business Logistics (21:1), 2000, pp. 95-120.

Weill, P., and Broadbent, M. Leveraging the Infrastructure: How Market Leaders Capitalize on Information Technology, Harvard Business School Press, Boston, 1998.

Zahra, S., and Covin, J. "Business Strategy, Technology Policy and Firm Performance," Strategic Management Journal (14:6), 1993, pp. 451-478.

Zahra, S. A., and George, G. "The Net-Enabled Business Innovation Cycle and the Evolution of Dynamic Capabilities," Information Systems Research (13:2), 2002, pp. 147-150.

\section{About the Authors}

Arun Rai is the Harkins Professor in the Center for Process Innovation and Department of Computer Information Systems at Georgia State University. His research has appeared in Decision Sciences, European Journal of Operations Research, IEEE Transactions on Engineering Management, Information Systems Research, Journal of Management Information Systems, MIS Quarterly, and other journals. He has served, or serves, on the editorial boards for Decision Sciences, IEEE Transactions on Engineering Management, Information Systems Research, Journal of Strategic Information Systems, and MIS Quarterly, among others. Leading corporations, including A. T. Kearney, Bozell Worldwide, Daimler-Chrysler, Gartner, IBM, UPS, and SAP, have sponsored his research.

Ravi Patnayakuni is an associate professor of information systems in the Department of Accounting and Information Systems at the University of Alabama in Huntsville. His research focuses on supply chain partnerships, information technology value, and knowledge management. His research has been published in Journal of Management Information Systems, Communications of the ACM, Omega, Communications of the AIS, and Information Systems Journal. He received his Ph.D. from Southern Illinois University at Carbondale in 1997.

Nainika Seth is an assistant professor of information systems in the Department of Accounting and Information Systems at the University of Alabama in Huntsville. She received her Ph.D. from Southern Illinois University at Carbondale in 2002. Her research interests include IT infrastructure, IT value, and the role of IT in supply chains. Her research has been published in Communications of the ACM, Omega, and Information Resources Management Journal and presented at the International Conference on Information Systems. 


\section{Appendix A}

\section{Summary Analysis of the Measurement Model: Factor Structure, ${ }^{a}$ Composite Reliability, ${ }^{b}$ and Average Variance Extracted ${ }^{c}$}

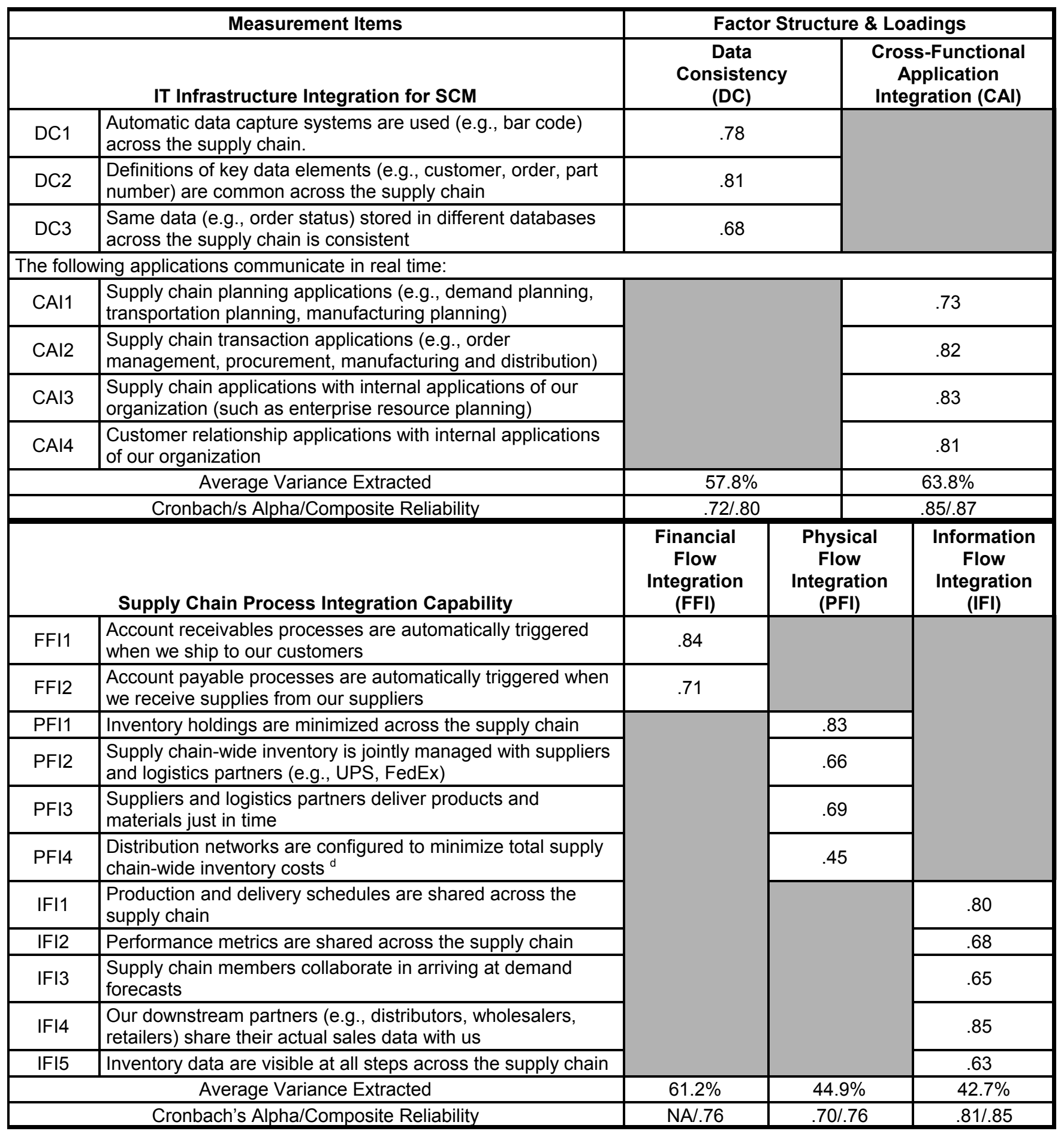




\begin{tabular}{|c|c|c|c|c|}
\hline \multicolumn{2}{|r|}{ Measurement Items } & \multicolumn{3}{|c|}{ Factor Structure \& Loadings } \\
\hline \multicolumn{2}{|r|}{ Firm Performance } & $\begin{array}{l}\text { Operational } \\
\text { Excellence } \\
\text { (OE) }\end{array}$ & $\begin{array}{c}\text { Revenue } \\
\text { Growth } \\
\text { (RG) }\end{array}$ & $\begin{array}{c}\text { Customer } \\
\text { Relationship } \\
\text { (CR) }\end{array}$ \\
\hline OE1 & Product delivery cycle time & .68 & & \\
\hline OE2 & Timeliness of after sales service & .81 & & \\
\hline OE3 & $\begin{array}{l}\text { Productivity improvements (e.g., assets, operating costs, } \\
\text { labor costs) }\end{array}$ & .77 & & \\
\hline RG1 & Increasing sales of existing products & & .83 & \\
\hline RG2 & $\begin{array}{l}\text { Finding new revenue streams (e.g., new products, new } \\
\text { markets) }\end{array}$ & & .83 & \\
\hline CR1 & Strong and continuous bond with customers & & & .74 \\
\hline CR2 & Precise knowledge of customer buying patterns & & & .92 \\
\hline & Average Variance Extracted & $57.1 \%$ & $69.1 \%$ & $70.0 \%$ \\
\hline & Cronbach's Alpha/Composite Reliability & $.66 / .80$ & $\mathrm{NA} / .82$ & $\mathrm{NA} / .82$ \\
\hline \multicolumn{2}{|r|}{ Consumer Demand Predictability (Control Variable) } & & & \\
\hline CD1 & There is a high margin of error in product forecasts & \multicolumn{3}{|c|}{.80} \\
\hline CD2 & Products have a short life cycle (less than 1 year) & \multicolumn{3}{|c|}{.80} \\
\hline & Average Variance Extracted & \multicolumn{3}{|r|}{$63.8 \%$} \\
\hline & Cronbach's Alpha/Composite Reliability & \multicolumn{3}{|c|}{$\mathrm{NA} / .78$} \\
\hline
\end{tabular}

Notes:

a. Rotated factor solution based on principal component analysis with varimax rotation. All cross-loadings below .40 are suppressed.

b. Internal consistency was calculated using Cronbach's alpha and a measure of composite reliability proposed by Fornel and Larcker (1981) for assessing internal consistency of constructs in structural equation models using the formula $\frac{\left(\sum \lambda_{y i}\right)^{2}}{\left(\sum \lambda_{y i}\right)^{2}+\sum \operatorname{Var}\left(\varepsilon_{i}\right)}$ where $\operatorname{Var}\left(\varepsilon_{\mathrm{i}}\right)=1-\lambda_{\mathrm{yi}}{ }^{2}$ and $\lambda$ is the item loading and $\varepsilon$ is the error. Cronbach's alpha is not reported for two-item constructs.

c. Average variance extracted is calculated using the formula $\frac{\sum \lambda_{y i}{ }^{2}}{\sum \lambda_{y i}{ }^{2}+\sum \operatorname{Var}\left(\varepsilon_{i}\right)}$ where $\operatorname{Var}\left(\varepsilon_{\mathrm{i}}\right)=1-\lambda_{\mathrm{yi}}{ }^{2}$ and $\lambda$ is the item loading and $\varepsilon$ is the error.

d. The item had a loading of .45 with information flow integration. However, after carefully evaluating the item, it was retained as part of physical flow integration due to content validity considerations. 


\section{Appendix B}

\section{Item-Construct Correlation}

\begin{tabular}{|c|c|c|c|c|c|c|c|c|c|c|}
\hline \multirow[b]{2}{*}{ Items } & \multicolumn{10}{|c|}{ Constructs } \\
\hline & DC & CAI & FFI & PFI & IFI & OE & RG & CR & CD & SZ \\
\hline DC1 & .751 & .304 & .081 & .229 & .296 & .155 & .102 & .088 & .236 & -.234 \\
\hline DC2 & .850 & .505 & .203 & .356 & .523 & .280 & .109 & .169 & .320 & .011 \\
\hline DC3 & .789 & .470 & .214 & .302 & .513 & .254 & .165 & .164 & .197 & -.026 \\
\hline CAl1 & .513 & .822 & .052 & .296 & .437 & .265 & .215 & .178 & .135 & -.063 \\
\hline $\mathrm{CAl} 2$ & .487 & .855 & .122 & .156 & .238 & .185 & .054 & .076 & .206 & -.014 \\
\hline $\mathrm{CAl} 3$ & .453 & .851 & .280 & .180 & .324 & .146 & .156 & .079 & .161 & -.008 \\
\hline CAl4 & .362 & .787 & .208 & .200 & .373 & .197 & .085 & .102 & -.010 & .024 \\
\hline FFI1 & .074 & .078 & .784 & .058 & -.018 & .115 & -.174 & .114 & -.037 & -.023 \\
\hline FFI2 & .263 & .278 & .867 & .333 & .312 & .271 & .081 & .122 & .085 & .007 \\
\hline PFI1 & .257 & .301 & .248 & .766 & .320 & .166 & .259 & .241 & .034 & .025 \\
\hline PFI2 & .211 & .113 & .284 & .743 & .444 & .194 & .158 & .181 & .206 & -.160 \\
\hline PFI3 & .257 & .147 & .246 & .667 & .363 & .206 & .227 & .188 & .053 & -.067 \\
\hline PFI4 & .332 & .245 & -.010 & .662 & .462 & .311 & .239 & .363 & .164 & .014 \\
\hline IFI1 & .405 & .294 & .207 & .479 & .732 & .162 & .251 & .066 & .080 & -.066 \\
\hline IFI2 & .418 & .208 & .174 & .437 & .816 & .250 & .208 & .097 & .047 & -.114 \\
\hline IFI3 & .441 & .213 & .095 & .372 & .806 & .272 & .140 & .213 & .100 & .016 \\
\hline IFI4 & .306 & .254 & .180 & .355 & .696 & .201 & .185 & .138 & -.031 & -.092 \\
\hline IFI5 & .547 & .579 & .136 & .405 & .727 & .249 & .280 & .087 & .163 & .021 \\
\hline OE1 & .170 & .149 & .108 & .212 & .214 & .782 & .233 & .316 & .037 & -.030 \\
\hline OE2 & .251 & .225 & .293 & .205 & .268 & .807 & .119 & .369 & -.066 & .051 \\
\hline OE3 & .270 & .177 & .181 & .250 & .244 & .736 & .222 & .239 & .002 & -.004 \\
\hline RG1 & .181 & .155 & .032 & .290 & .351 & .349 & .850 & .426 & -.086 & .125 \\
\hline RG2 & .094 & .106 & -.091 & .267 & .166 & .105 & .887 & .141 & .026 & .076 \\
\hline CR1 & .169 & .053 & .203 & .233 & .066 & .420 & .252 & .858 & .103 & .018 \\
\hline CR2 & .125 & .173 & .052 & .338 & .209 & .282 & .295 & .886 & .033 & .077 \\
\hline CD1 & .120 & .026 & -.030 & .035 & .000 & -.058 & -.024 & -.069 & .733 & -.137 \\
\hline CD2 & .337 & .185 & .120 & .189 & .132 & .033 & -.040 & .155 & .852 & -.194 \\
\hline
\end{tabular}

